\title{
Assessing Exposure to Chloroform in Swimming Pools Using Physiologically Based Toxicokinetic Modeling
}

\author{
Cyril Catto ${ }^{1}$, Ginette Charest-Tardif ${ }^{1}$, Manuel Rodriguez ${ }^{2} \&$ Robert Tardif $^{1}$ \\ ${ }^{1}$ Département de Santé Environnementale et Santé au Travail, École de Santé Publique de l'Université de \\ Montréal, C. P. 6128 Succursale Centre-Ville, Montréal (Québec), Canada \\ ${ }^{2}$ Chaire de Recherche en Eau Potable, Département D'aménagement du Territoirel, Université Laval, 1624 \\ Pavillon F. A. Savard, Ste-Foy (Québec), Canada \\ Correspondence: Robert Tardif, Département de Santé Environnementale et Santé au Travail, École de Santé \\ Publique de l'Université de Montréal, C. P. 6128 Succursale Centre-Ville, Montréal (Québec), Canada. Tel: \\ 1-514-343-6111 (1515). E-mail: robert.tardif@umontreal.ca
}

Received: February 17, 2012 Accepted: March 1, 2012 Online Published: June 18, 2012

doi:10.5539/ep.v1n2p132 URL: http://dx.doi.org/10.5539/ep.v1n2p132

\begin{abstract}
This work examines the use of physiologically based toxicokinetic (PBTK) modeling to assess exposure to the most abundant disinfection by-product (DBP), chloroform (TCM), to be found in indoor swimming pools. Real exposure scenarios including environmental (water and air levels) and biological (alveolar air or blood levels) data extracted from the literature were simulated. Predicted biological data matched up well with the reported actual levels, thereby confirming the reliability of this approach. Relative contributions of inhalation and dermal absorption to the total body burden were estimated and compared to the inconsistent results of reported studies. The PBTK simulations served to explain this inconsistency, suggesting that the prevalence of each pathway depends on environmental concentrations and on the ratio between air and water levels in particular. Likewise, comparisons between 24-h typical household and typical 1- or 2-h swimming pool exposure scenarios point to the preponderance of the latter.
\end{abstract}

Keywords: disinfection by-products, trihalomethanes, chloroform, exposure assessment, swimming pools, biological exposure, physiologically based toxicokinetic modeling

\section{Introduction}

Chloroform (TCM) is by far the most abundant drinking water contaminant among disinfection by-products (DBPs). It belongs to the category of the trihalomethanes (THMs) that raise public health concerns, given their potential adverse effects (i.e., carcinogenicity and reprotoxicity) (Grazuleviciene et al., 2011; Grellier et al., 2010; Nieuwenhuijsen et al., 2009; Tardiff, Carson, \& Ginevan, 2006; Villanueva et al., 2007). It is a well known fact that exposure to volatile and lipophilic TCM can occur through ingestion, inhalation and dermal absorption (Weisel \& Jo, 1996). Excluding ingestion, inhalation is commonly regarded as the main route of absorption (Erdinger et al., 2004; Lévesque et al., 1994), but it is also reported that dermal absorption might be dominant (up to $80 \%$ ) (Lindstrom, Pleil, \& Berkoff, 1997). Likewise, various sources can contribute to exposure to TCM: it can occur through household water use activities (e.g., showering, washing) (Nuckols et al., 2005) but also in swimming pools where conditions are conducive to a potentially high exposure to disinfection by-products (DBPs) for occasional or regular attendees (e.g., children, pregnant women, competitors), as well as workers (e.g., lifeguards) (AFSSET, 2010). As a matter of fact, numerous factors related to technical requirements or individual behaviors can contribute to increasing swimming pool exposure to these chemical contaminants, in particular their formation in high quantities and their absorption by the human body (e.g., water re-circulation, high doses of applied disinfectants, poor ventilation in indoor swimming pools, continuous DPB precursor loading from swimmers and the physiological impact of physical exercise resulting in greater pulmonary ventilation) (Zwiener et al., 2007).

Most studies dealing with the issue of exposure to THMs and especially to TCM in swimming pools examined the use of biological markers (e.g., blood, alveolar air and urine) to quantitatively assess this exposure among leisure and competitive swimmers (Aggazzotti, Fantuzzi, Righi, \& Predieri, 1998; Aggazzotti et al., 1993; Aggazzotti, Fantuzzi, Tartoni, \& Predieri, 1990; Cammann \& Hubner, 1995; Caro \& Gallego, 2008a, 2008b; 
Caro, Serrano, \& Gallego, 2006, 2007; Faust, Faust, \& Cammann, 1993; Lourencetti et al., 2010). Only a few studies investigated occupational exposure to TCM among workers (Caro \& Gallego, 2007, 2008a; Fantuzzi et al., 2001; Fantuzzi et al., 2010); however, health risks were rarely assessed (AFSSET, 2010; Lee, Ha, \& Zoh, 2009; Lévesque et al., 2000; Panyakapo, Soontornchai, \& Paopuree, 2008). Some studies aimed more specifically at quantifying the relative contributions of each exposure pathway to the total exposure (Beech, 1980; Erdinger et al., 2004; Lévesque et al., 1994), while others documented environmental occurrence only (Bessonneau, Derbez, Clement, \& Thomas, 2011; Chu \& Nieuwenhuijsen, 2002; Lee, Jun, Lee, Eom, \& Zoh, 2010; Sa, Boaventura, \& Pereira, 2011; Sacré, Schwenk, Jovanovic, Wallner, \& Gabrio, 1996; Simard, 2009; Weaver et al., 2009). The relationship with biomarkers of genotoxicity and respiratory effects was investigated recently (Font-Ribera et al., 2010; Kogevinas et al., 2010).

So far, little effort has been devoted to account for swimming pool exposure in epidemiological investigations on potential adverse effects of TCM and other THMs. Indeed, most studies consider only household exposure (i.e., tap water use through ingestion, showering and bathing) and fail to address the potential contribution of swimming (i.e., frequency of pool attendance) as a possible source of additional exposure (Dodds et al., 2004; Gallagher, Nuckols, Stallones, \& Savitz, 1998; Hinckley, Bachand, \& Reif, 2005; Hoffman et al., 2008a, 2008b; MacLehose et al., 2008; Porter, Putnam, Hunting, \& Riddle, 2005; Savitz et al., 2006). Recently, however, the potential importance of swimming pool exposure emerged as a growing concern (Font-Ribera, Kogevinas, Nieuwenhuijsen, Grimalt, \& Villanueva, 2010; Villanueva et al., 2006; Villanueva, Gagniere, Monfort, Nieuwenhuijsen, \& Cordier, 2007). As a result, new studies examine this contribution by at least documenting the time spent by attendees in the swimming pools (Levallois et al., 2012; Villanueva, Cantor et al., 2007) and/or by using algorithms to estimate personal uptakes while swimming (Patelarou et al., 2011; Villanueva et al., 2011). Such algorithms consist of multiplying the TCM concentration in pool water and the time an individual spends swimming by an uptake factor proposed by Villanueva et al. (2007) on the basis of previous work by Whitaker et al. (2003) and using data from Aggazzotti et al. (1995). The result is the prediction of an indicator of internal exposure representative of the quantity of TCM absorbed in the blood while swimming.

To our knowledge, only two other methods can serve to quantify swimming pool exposure to TCMs. The swimmer exposure assessment model (SWIMODEL) is a tool developed by the United States Environmental Protection Agency (U.S.E.P.A) on the basis of previous work by Beech et al. (Beech, 1980). It uses typical equations describing the absorption of contaminants by an organism. It estimates the swimmer's chemical intake. Dyck et al. (2011) compared this model with a robust and powerful level III fugacity model they developed to estimate exposure to THMs in indoor swimming pools. However, like the SWIMODEL, it does not consider the kinetics of the contaminant entering the human body and only predicts absorbed doses.

Another interesting and more practical alternative is physiologically based toxicokinetic (PBTK) modeling (Krishnan, Haddad, Beliveau, \& Tardif, 2002). It consists of simulating the fate of a toxicant in a living organism (animal or human) characterized with physiological parameters that consider the kinetic properties of the studied substance in terms of its absorption, distribution, metabolism and excretion. It is based on a conceptual representation of a body divided into several compartments. Blood (venous and arterial) circulation interconnects these compartments so that the chemical may circulate into the conceptual body. Differential equations express mass balances between input and output amounts of chemical in each compartment. Integrating these equations allows an estimation of contaminant concentrations versus time in each compartment.

In this context, this study examines the relevance, including feasibility and efficiency, of using PBTK modeling to simulate exposure to TCM in swimming pools and predict biological levels of this contaminant in individuals. Indeed, such an approach was previously developed in the course of field investigations by Lévesque et al. (2000). More specifically, this paper: (i) compares the predictions of internal concentration using PBTK modeling with actual biological indicator levels and identifies the main factors influencing these estimates; (ii) compares the relative contributions of dermal and respiratory pathways to global TCM exposure while present at a swimming pool; and (iii) compares swimming pool exposure contributions with household exposure. Finally, a comparative perspective is outlined between the various approaches available to assess exposure to TCM in swimming pools.

\section{Methodology}

\subsection{Database}

Data were extracted from the literature among investigations involving exposure assessment to TCM of indoor swimming pool attendees (volunteers for an experiment or occasional visitors). We selected only studies that reported both TCM environmental levels (i.e., concentrations in the water and air) and TCM biological levels 
(i.e., blood or alveolar air concentrations). We then excluded studies that only reported the mean of TCM environmental levels over various sampling sessions or sites. We focused on cases of exposure resulting from short attendance (one or two hours) rather than on the longer occupational exposure of workers (shift of several hours). Table 1 briefly describes the five studies finally selected for simulation purposes. Each took place at a single indoor swimming pool. The wide range of reported environmental contamination levels is shown in Table 2. These data encompass various geographical areas and reflect possible cultural differences in swimming pool operational management.

\subsection{PBTK Simulations}

\subsubsection{PBTK Modeling}

A PBTK model (ACSLXtreme ${ }^{\circledR}$ ) for TCM developed by our team (Haddad et al. 2006) was used to simulate the various swimming pool exposure scenarios previously identified. It was initially developed to estimate household exposure through tap water consumption, showering and inhalation of ambient air (in the shower room and/or in the rest of the house). Indeed, a volatilization model for TCM (VTM) was developed and integrated into the PBTK model to predict TCM ambient air concentrations resulting from the volatilization of water.

The model is based on mathematical formulas explaining the fate of a chemical in a living organism characterized by physiological parameters (e.g., body weight and body surface area) and represented by various compartments linked together by blood circulation. Actually, these equations express mass balances between inputs and outputs of the studied chemical at each compartment. In addition to lungs, the PBTK model comprises five compartments (e.g., skin, liver, adipose tissue, poorly and richly perfuse tissues) as shown in scheme 1 . The amount of chemical accumulated in each compartment $(\mathrm{At}, \mu \mathrm{g})$ is calculated from the following equations:

$$
\frac{d A t}{d t}=Q t\left(C a-\frac{C t}{P t}\right)
$$

Where Qt: blood flow through compartment $\mathrm{t}(\mathrm{L} / \mathrm{min})$

$\mathrm{Ca}$ : arterial blood concentration $(\mu \mathrm{g} / \mathrm{L})$

$\mathrm{Ct}$ : concentration in the compartment $\mathrm{t}(\mu \mathrm{g} / \mathrm{L})$

Pt: tissue:blood partition coefficient (unitless)

Only liver metabolism was considered. It was assumed to be a saturable process described as follows:

$$
\frac{d A m e t}{d t}=\frac{V M A X \times C v l}{K m+C v l}
$$

Where Amt: the amount of metabolized chemical $(\mu \mathrm{g})$

VMAX: maximal metabolic rate $(\mu \mathrm{g} / \mathrm{min})$

Cvl: concentration in the venous blood from liver $(\mu \mathrm{g} / \mathrm{L})$

Km: Michaelis-Menten affinity constant $(\mu \mathrm{g} / \mathrm{L})$

This model considers multi-route exposure (e.g., inhalation, dermal absorption and ingestion), but also considers independently only one or two exposure pathways. Pulmonary exchanges describing inhalation are modeled with the following steady-state equation:

$$
C a=\frac{Q c \times C v}{Q c+Q a l v / P b}+\frac{Q a l v \times C i}{Q c+Q a l v / P b}
$$

Where Ca: arterial blood concentration $(\mu \mathrm{g} / \mathrm{L})$

Qc: cardiac output (L/min)

$\mathrm{Cv}$ : venous concentration $(\mu \mathrm{g} / \mathrm{L})$

Qalv: pulmonary ventilation ( $\mathrm{L} / \mathrm{min})$

$\mathrm{Pb}$ : blood:air partition coefficient (unitless)

Ci: concentration in inhaled air $(\mu \mathrm{g} / \mathrm{L})($ Cinh or Cinhs $)$

The two terms of this equation represent the portion of arterial blood from the systemic circulation (actually 
absorbed) $\left(\mathrm{Ca}_{\mathrm{a}}\right)$ and the portion from inhaled air (unabsorbed) $\left(\mathrm{Ca}_{\mathrm{na}}\right)$, respectively. The latter allows the calculation of the actual dose absorbed through inhalation (Di, $\mu \mathrm{g}$ ) using a mass balance equation similar to Eq.1:

$$
\frac{d D i}{d t}=\operatorname{Qalv}\left(C i-\frac{C a_{n a}}{P b}\right)
$$

$\mathrm{Cv}$ is the result of the mixture of venous blood from each compartments and is calculated as follows :

$$
C v=\frac{\sum_{t}\left(C v t^{*} Q t\right)}{Q c}
$$

where Cvt: concentration in the venous blood from compartment $\mathrm{t}(\mu \mathrm{g} / \mathrm{L})$

The amount of dermally absorbed chemical (Dder, $\mu \mathrm{g}$ ) is calculated with the following equation:

$$
\frac{d D d e r}{d t}=(K p \times S U R F / 1000) \times\left(C w a t-\frac{C s k}{P s w}\right)
$$

where Kp: permeability constant $(\mathrm{cm} / \mathrm{min})$

SURF: body surface $\left(\mathrm{cm}^{2}\right)$

Cwat: concentration in the water $(\mu \mathrm{g} / \mathrm{L})$

Csk: concentration in the skin $(\mu \mathrm{g} / \mathrm{L})$

Psw: skin: water partition coefficient (unitless)

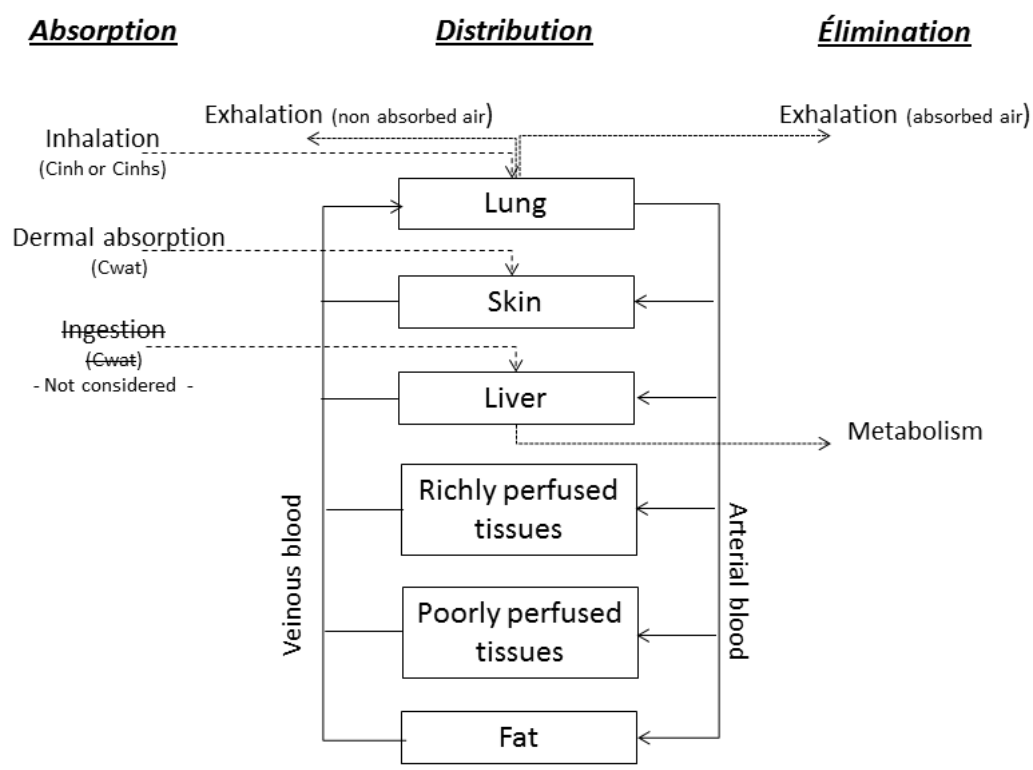

Scheme 1. Conceptual representation of PBTK modeling

For each scenario, we predicted TCM levels in alveolar air or blood versus time, the relative contribution of dermal and respiratory pathways to estimated total exposure and the total intake of TCM as absorbed quantity. Then appropriate estimates were compared to the actual field data reported in the literature. Prior to each simulation, we carried out a careful parameterization to define environmental concentrations, the physiological characteristics of the "modeled" individual and exposure conditions as realistic as possible to those actually reported.

\subsubsection{Environmental Parameterization}

The data regarding the water and air levels reported by the authors of the selected studies (see Table 2) were used to set the PBTK model (the VTM module was never used to estimate environmental concentration; as previously mentioned, studies with missing environmental data were systematically excluded). When authors reported a 
pre- and/or post-exposure periods in poorly contaminated areas for biological sampling before or following the main studied exposure event, we accounted for a slight inhalational exposure to a basic TCM level in ambient air When this environmental level was not indicated by authors, we arbitrarily assumed it was equal to the baseline concentration measured before the exposure experiment in the alveolar air of the participants. The current work of Lourencetti et al. (2010) supports this assumption.

\subsubsection{Physiological Parameterization}

When no other information was available, standard physiological characteristics for an individual were considered: (i.e., body weight of $70 \mathrm{~kg}$ and a body surface of $18000 \mathrm{~cm}^{2}$ ). In the cases when body surface (SURF) was unknown, it was estimated from body weight (BW) using a formula proposed by Costeff (1966). All other physiological parameters used for modeling were adjusted according to these two parameters based on classic allometric relationships and by assuming standard values of the percentages of body weight and cardiac output for the various compartments (Tardif, Droz, Charest-Tardif, Pierrehumbert, \& Truchon, 2002). These values were sometimes adjusted to consider the physiological impact associated with a possibly demanding physical effort (e.g., intense training). By default, the "simulated" subjects were assumed to have standard physiology corresponding to rest. Physiological characteristics corresponding to a workload equivalent to $50 \mathrm{~W}$ or $100 \mathrm{~W}$ were occasionally considered to improve simulations according to the intensity of physical exercise reported in a given study (for instance, in cases of hard training) (Lévesque et al., 2000).

\subsubsection{Exposure Conditions}

Water ingestion during swimming is allegedly irrelevant (less than $50 \mathrm{~mL}$ of water might be swallowed) (Dufour, Evans, Behymer, \& Cantu, 2006) and was consequently ignored, as were specific and low contributions relative to aural (both buccal and sublingual), as well as the orbital and nasal absorptions considered by Beech (1980).

Swimming was assimilated with showering, which consisted of accounting for dermal absorption (from TCM concentration in the water $-\mathrm{C}_{\mathrm{wat}}$ ) and inhalation of ambient air (from TCM concentration at the surface of the pool water $-\mathrm{C}_{\text {inhs }}$ ). Resting, sitting on pool edges or walking around the pool was simulated by considering only inhalation of ambient air (from suitable TCM concentration in the indoor air $-\mathrm{C}_{\mathrm{inh}}$ ), as were the pre- and/or post-exposure periods before and/or following reported monitored activities. When a particular experimental design was established by the authors to segregate a single route of exposure (e.g., with scuba tanks or diving suits to prevent respiratory or dermal exposure, respectively), other pathways were not taken into account in our simulations. Very precise information was available in the selected studies in terms of activity timing and duration. Only slight cases of imprecision (i.e., lack of information) emerged occasionally, for example the precise time between end of swimming, the exact timetable of biological sampling and departure from the swimming pool.

\subsubsection{Comparative Household Exposure Scenarios}

The average scenario of exposure proposed by Haddad et al. (2006) was used as a reference to simulate a typical TCM exposure at home. This scenario comprised the consumption of five glasses of water (TCM water concentration $\left[\mathrm{C}_{\text {wat }}\right]=50 \mu \mathrm{g} / \mathrm{L}$ ), a 10-minute shower (same TCM water concentration; TCM air concentration in shower $\left.\left[C_{\text {inhs }}\right]=530 \mu \mathrm{g} / \mathrm{m}^{3}\right)$ and inhalation, over a whole day $(24 \mathrm{~h})$, at the level corresponding to ambient air (TCM predicted by the VTM from TCM water concentration $\left[\mathrm{C}_{\mathrm{inh}}\right] \approx 3 \mu \mathrm{g} / \mathrm{m}^{3}$ ). We also reconstructed and simulated some scenarios by adjusting household exposure conditions in cases involving low and high contamination (data not shown) corresponding to the data reported by Nuckols et al. (2005). The mean and maximal TCM blood levels and absorbed quantities predicted by our models in these two typical cases of household exposure were compared to those reported in the various study cases of pool water exposure previously simulated.

\section{Results}

A total of 23 scenarios involving swimmers exposed to TCM by both dermal and inhalational pathways during short period of exercise (from 45 to $120 \mathrm{~min}$ ) were identified from the five selected studies described in Table 1 and simulated using PBTK modeling. Table 2 summarizes the parameterization corresponding to each scenario. A scenario was defined each time both the levels of TCM in water and air during an exposure event and the average level in blood or exhaled air for a group of participants following this event were reported in the selected studies.

The PBTK model allowed a quite good fit of the experimental data. Figure 1 illustrates that the predictions of TCM alveolar air adequately estimate the biological measurements reported. However, while simulating additional scenarios involving a single route of exposure (i.e., dermal absorption or inhalation but not both), our 
predictions appear less reliable in the case of dermal absorption (Figure 1). Indeed, the worst match was for the data reported by Lindstrom (1997) (Figure 2), who estimated a very important contribution of dermal absorption while testing a new device for collecting self-administered breathed air samples. The very intense physiological effort involved by swimmers may have contributed to such a high contribution.
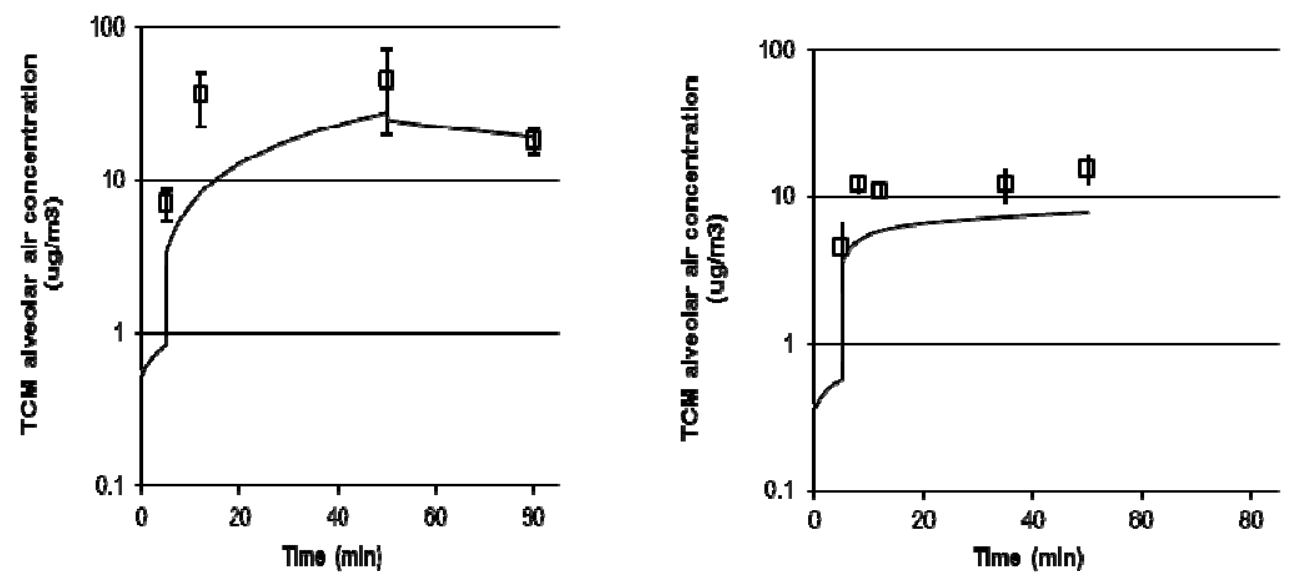

A

B
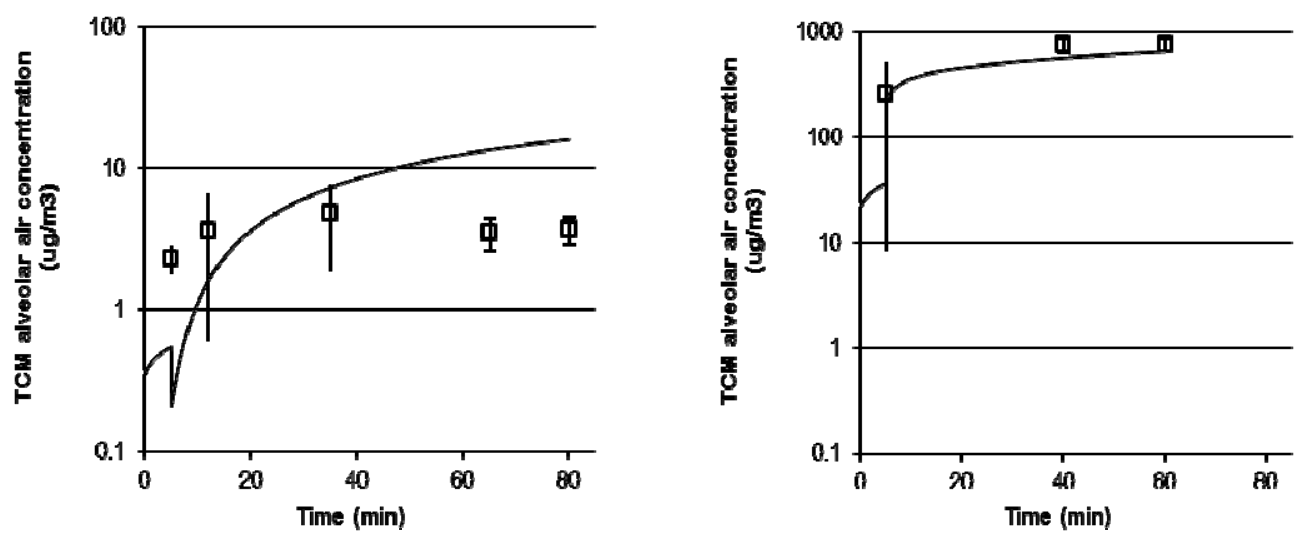

$\mathrm{C}$

$\mathrm{D}$
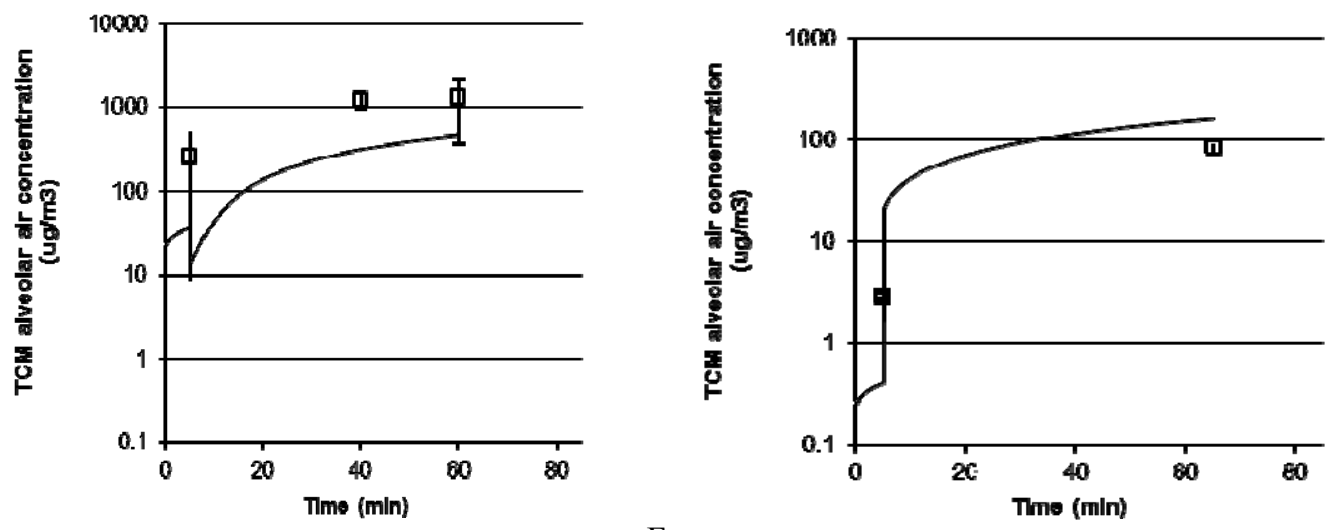

E

$\mathrm{F}$

Figure 1. Simulated (lines) and observed (symbols - mean $\pm \mathrm{SD}$ ) concentrations of TCM in alveolar air according to various scenarios previously described (A, D, F) and additional data extracted from literature $(\mathrm{B}, \mathrm{C}$,

E). A: Wil_\#1; B: Wil_\#3 with inhalation only, Cwat $=17 \mu \mathrm{g} / \mathrm{L}, \mathrm{Cinhs}=39.8 \mu \mathrm{g} / \mathrm{m}^{3}, \mathrm{Cinh}=4.2 \mu \mathrm{g} / \mathrm{m}^{3}$ and post-exposure at rest; $\mathrm{C}=$ Wil_\#2 with dermal absorption only, Cwat $=16.5 \mu \mathrm{g} / \mathrm{L}, \mathrm{Cinhs}=65.3 \mu \mathrm{g} / \mathrm{m}^{3}, \mathrm{Cinh}=$ $4 \mu \mathrm{g} / \mathrm{m}^{3}$ and $75 \mathrm{~min}$ swimming; D: Lev_1\#; ; E: Lev_1\# with inhalation exposure only, Cwat $=567.5 \mu \mathrm{g} / \mathrm{L}$ and Cinhs $=637 \bar{\mu} \mu \mathrm{g} / \mathrm{m}^{3} ; \mathrm{F}$ : Car_1\# 
Table 1. Description of selected published studies on swimming pool exposure assessment to TCM

\begin{tabular}{|c|c|c|c|c|c|}
\hline $\begin{array}{l}\text { Referen } \\
\text { ce }\end{array}$ & $\begin{array}{l}\text { Objective } \\
\text { Place }\end{array}$ & esign & articipants & $\begin{array}{l}\text { mental } \\
\mathrm{g}\end{array}$ & $\begin{array}{l}\text { ical } \\
\text { ng }\end{array}$ \\
\hline $\begin{array}{l}\text { Lévesq } \\
\text { ue et } \\
\text { al., } \\
1994\end{array}$ & $\begin{array}{l}\text { To evaluate } \\
\text { dermal and } \\
\text { respiratory } \\
\text { TCM } \\
\text { absorption. } \\
\text { Québec, Canada }\end{array}$ & $\begin{array}{l}7 \text { sessions of 55-min training } \\
\text { ( } 3 \text { periods of } 15 \text { min separated } \\
\text { by 5-min periods of rest) with } \\
\text { forced increasing TCM water } \\
\text { levels between each session. } \\
\text { Experimental design } \\
\text { investigating impact of } \\
\text { physical activities and isolated } \\
\text { impact of dermal exposure }\end{array}$ & $\begin{array}{l}11 \text { males } \\
\text { members of } \\
\text { a scuba } \\
\text { diving } \\
\text { association } \\
\text { (19-38 years } \\
\text { old) }\end{array}$ & $\begin{array}{l}\text { Every } 10 \text { minutes } \\
\text { during experiment in } \\
\text { the middle of the pool } \\
\text {-Water at a depth of } 20 \\
\mathrm{~cm} \\
\text {-Air in respiratory zone } \\
\text { of swimmers }\end{array}$ & $\begin{array}{l}\text { Three alveolar air } \\
\text { sampling for each } \\
\text { swimmer before, } \\
\text { during and at the } \\
\text { end of the session }\end{array}$ \\
\hline $\begin{array}{l}\text { Wilson, } \\
1995\end{array}$ & $\begin{array}{l}\text { To compare the } \\
\text { relative } \\
\text { contribution of } \\
\text { dermal and } \\
\text { inhalational } \\
\text { pathways to } \\
\text { TCM uptake. } \\
\text { Albany, USA }\end{array}$ & $\begin{array}{l}7 \text { breath sampling events } \\
\text { regarding various activities } \\
\text { (resting on the pool edge, } \\
\text { walking, swimming) and } \\
\text { considering single or } \\
\text { multi-route exposure }\end{array}$ & $\begin{array}{l}7 \quad \text { males } \\
\text { volunteers } \\
\text { (29-42 years } \\
\text { old) }\end{array}$ & $\begin{array}{l}\text { - } 3 \text { concurrent water } \\
\text { samples at a depth of } 20 \\
\mathrm{~cm} \text { in various moments } \\
\text { - air in respiratory zone }\end{array}$ & $\begin{array}{l}\text { Alveolar air } \\
\text { concentration of } \\
\text { each subject before } \\
\text { entering the pool and } \\
\text { regularly during the } \\
\text { exposure period } \\
\text { (usually } 7 \text { and } 30 \\
\text { min after beginning) } \\
\text { and at the end }\end{array}$ \\
\hline $\begin{array}{l}\text { Lindstr } \\
\text { om et } \\
\text { al., } \\
1997\end{array}$ & $\begin{array}{lr}\text { To test a } & \text { a } \\
\text { self-administere } \\
\text { d sample } \\
\text { collection } \\
\text { method r to } \\
\text { assess } & \text { TCM } \\
\text { alveolar air. } \\
\text { Montana, USA } \\
\end{array}$ & $\begin{array}{l}\text { A } 2 \text { h-typical and intense } \\
\text { training session of elite } \\
\text { college athletes }\end{array}$ & $\begin{array}{l}1 \text { male and } \\
1 \text { female }(23 \\
\text { and } 22 \text { years } \\
\text { old })\end{array}$ & $\begin{array}{l}\text { - } 2 \text { water samples (no } \\
\text { more precision) } \\
-1 \text { integrated whole-air } \\
\text { sample }(+30 \mathrm{~cm} \text { above } \\
\text { water surface at } \\
\text { mid-pool })+3 \text { punctual } \\
\text { whole-air grab samples }\end{array}$ & $\begin{array}{lr}\text { Intensive } & \\
\text { measurements } & \text { of } \\
\text { alveolar } & \text { air } \\
\text { concentrations } & \\
\text { during and } & \text { allowing exposure }\end{array}$ \\
\hline $\begin{array}{l}\text { Erdinge } \\
\text { r et al., } \\
2004\end{array}$ & $\begin{array}{l}\text { To investigate } \\
\text { the relative } \\
\text { contribution of } \\
\text { the different } \\
\text { pathways to } \\
\text { TCM exposure. } \\
\text { Heidelberg, } \\
\text { Germany }\end{array}$ & $\begin{array}{l}3 \text { distinct sessions of } 60 \mathrm{~min} \\
\text { exercising period. } \\
\text { Each session involved } 3 \\
\text { groups: swimmers with or } \\
\text { without scuba tanks, and } \\
\text { persons normally dressed } \\
\text { walking around the pool }\end{array}$ & $\begin{array}{l}\text { Between } 10 \\
\text { and } 17 \text { a } \\
\text { session. All } \\
\text { males, } \\
\text { members of } \\
\text { a scuba } \\
\text { diving club } \\
(26-58 \text { years } \\
\text { old) }\end{array}$ & $\begin{array}{l}\text {-Water : One sample by } \\
\text { session at a depth of } 10 \\
\mathrm{~cm} \\
\text {-Air: samples at } 20 \text { and } \\
150 \mathrm{~cm} \text { above the water } \\
\text { surface (respiratory } \\
\text { zones of swimmers and } \\
\text { lifeguards, respectively) }\end{array}$ & $\begin{array}{l}\text { Venous blood } \\
\text { concentrations } \\
\text { measured before } \\
\text { and at the end of } \\
\text { the exposure }\end{array}$ \\
\hline $\begin{array}{l}\text { Caro } \\
\text { and } \\
\text { Gallego, } \\
2008\end{array}$ & $\begin{array}{l}\text { To compare use of } \\
\text { alveolar air and } \\
\text { urine as } \\
\text { biomarkers of } \\
\text { exposure to TCM. } \\
\text { Cordoba, Spain }\end{array}$ & $\begin{array}{l}\text { One hour in the swimming } \\
\text { pool water without any } \\
\text { particular requirements }\end{array}$ & $\begin{array}{l}4 \text { males and } \\
8 \text { females } \\
(25-45 \text { years } \\
\text { old })\end{array}$ & $\begin{array}{l}-18 \text { water samples for } \\
2-4 \mathrm{~h}-5 \text { air } \\
\text { samples during } \\
\text { same time }\end{array}$ & $\begin{array}{l}\text { Triplicate alveolar } \\
\text { air samples within } \\
5 \text { min before and } \\
\text { after swimming }\end{array}$ \\
\hline
\end{tabular}

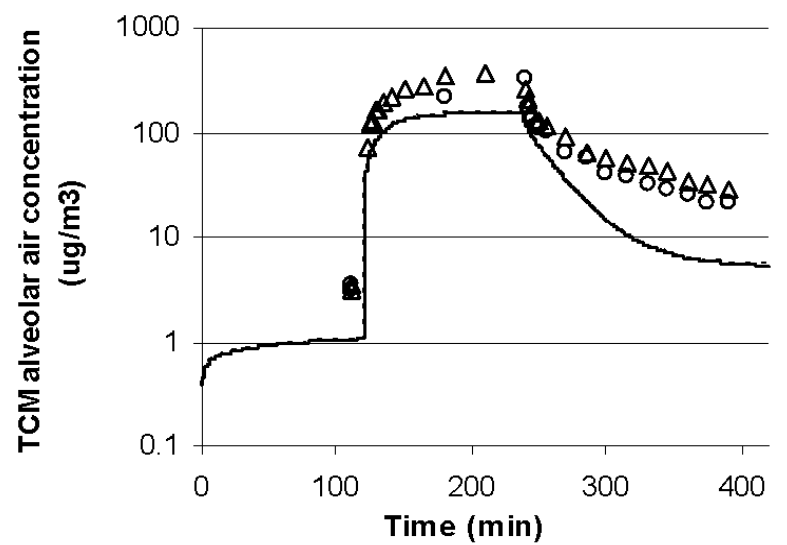

Figure 2. Simulated (line) and observed concentrations of TCM (triangles: male; circle: female) in alveolar air in swimmers. From Lindstrom et al. (1997) 
Erdinger et al. (2004) is the only selected case reporting measurements of blood levels of TCM. Figure 3 shows that the predictions of venous concentrations can be improved in the case of Erd_\#1 by assuming increasing levels of physiological activities (50W or 100W). However, for this case, no particular efforts in swimming exercise were reported. Nevertheless, participants were all members of a scuba diving club and many were accustomed to intense training. Lindstrom et al. (1997) did not measure, but rather estimated, the blood concentrations at the end of the swimming exercise. Their predictions $(1.81$ and $2.08 \mu \mathrm{g} / \mathrm{L}$ for the man and the woman, respectively) are comparable to ours (1.70 and $1.71 \mu \mathrm{g} / \mathrm{L}$, respectively).

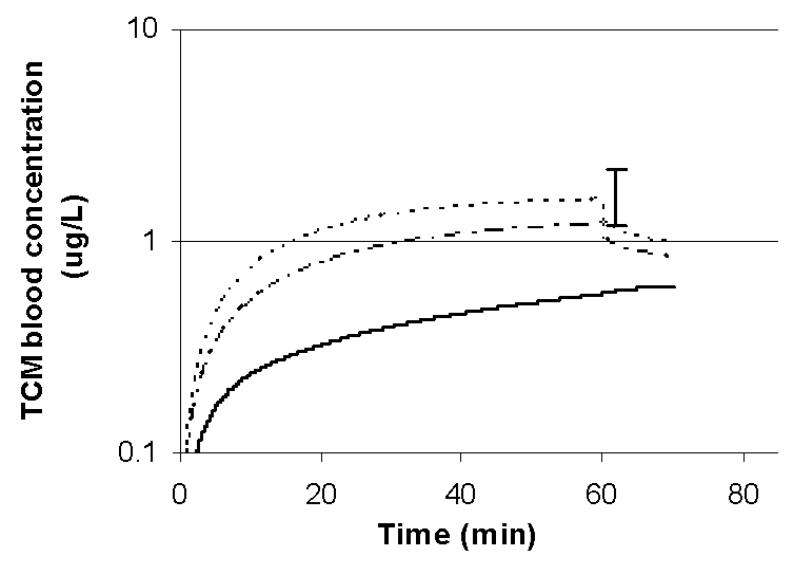

Figure 3. Simulated (full line) and range of observed venous concentrations (symbol) of TCM in swimmers corresponding to scenario Erd_\#1. Dotted lines represent the predicted levels assuming increasing physiological effort during swimming exercise (50W and $100 \mathrm{~W})$

Table 3 presents the results of the simulations of the exposure scenarios previously described (Table 2), including the peak venous concentrations ( $\mathrm{Cv}$ max), the total absorbed dose (AD) and the relative contribution of dermal (DERM) and respiratory (INHAL) pathways. Although these indicator values vary highly between the different studies, $\mathrm{Cv}$ max and $\mathrm{AD}$ increase consistently with increasing water and air contamination levels. $\mathrm{Cv}$ max are in

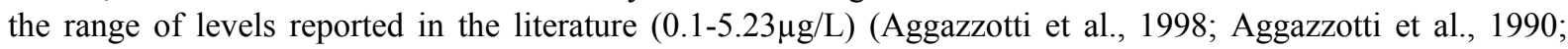
Aiking, van Acker, Scholten, Feenstra, \& Valkenburg, 1994; Cammann \& Hubner, 1995). Even for the scenarios extracted from Lévesque et al. (1994) with forced contamination resulting in extremely high environmental levels in comparison with typical measurements, the predicted ADs remain below the worst case TCM body burden of $128.8 \mu \mathrm{g} / \mathrm{kg}$ estimated by Beech (1980) while also assuming high water contamination $(500 \mu \mathrm{g} / \mathrm{L})$. However, ADs are generally higher than those estimated by Dyck et al. (2011) based on a fugacity approach.

Table 2. Simulated exposure scenarios for a typical swimmer exposed to TCM by all routes (dermal and inhalational) during short periods of exercise

\begin{tabular}{|c|c|c|c|c|c|c|}
\hline \multirow{2}{*}{\multicolumn{2}{|c|}{ Scenario reference }} & \multicolumn{3}{|c|}{$\begin{array}{l}\text { Environmental } \\
\text { parameterization }\end{array}$} & \multirow{2}{*}{$\begin{array}{l}\text { Physiological } \\
\text { characteristics }\end{array}$} & \multirow{2}{*}{ Exposure conditions } \\
\hline & & $\begin{array}{l}\text { Cwat } \\
(\mu \mathrm{g} / \mathrm{L})\end{array}$ & $\begin{array}{l}\text { Cinhs } \\
\left(\mu \mathrm{g} / \mathrm{m}^{3}\right)\end{array}$ & $\begin{array}{l}\text { Cinh } \\
\left(\mu \mathrm{g} / \mathrm{m}^{3}\right)\end{array}$ & & \\
\hline \multirow[t]{4}{*}{$\begin{array}{l}\text { Lévesque } \\
\text { et al., } 1994\end{array}$} & Lev_\#1 & 158.6 & 2492 & 260 & BW by default & $\begin{array}{l}\text { 5-min pre-exposure } \\
+55 \text {-min swimming }\end{array}$ \\
\hline & Lev_\#2 & 200 & 7325 & 260 & BW by default & $\begin{array}{l}5 \text {-min pre-exposure } \\
+\quad 55 \text {-min intense swimming } \\
(50 \mathrm{~W})\end{array}$ \\
\hline & Lev_\#3 & 307.1 & 5506 & 260 & BW by default & $\begin{array}{l}\text { 5-min pre-exposure } \\
+55 \text {-min swimming }\end{array}$ \\
\hline & Lev_\#4 & 553 & 7222 & 260 & BW by default & $\begin{array}{l}5 \text {-min pre-exposure } \\
+55 \text {-min swimming }\end{array}$ \\
\hline
\end{tabular}




\begin{tabular}{|c|c|c|c|c|c|c|}
\hline & Lev_\#5 & 538.3 & 8014 & 260 & BW by default & $\begin{array}{l}\text { 5-min pre-exposure } \\
+55 \text {-min swimming }\end{array}$ \\
\hline \multirow[t]{3}{*}{$\begin{array}{l}\text { Wilson, } \\
1995\end{array}$} & Wil_\#1 & 30.5 & 35 & 6 & $\begin{array}{l}\text { Mean BW of } \\
4 \text { participants }\end{array}$ & $\begin{array}{l}\text { 5-min pre-exposure } \\
+45 \text {-min swimming } \\
+30 \text {-min post-exposure }\end{array}$ \\
\hline & Wil_\#2 & 20.3 & 29.3 & 20.5 & $\begin{array}{l}\text { Mean BW of } \\
5 \text { participants }\end{array}$ & $\begin{array}{l}\text { 5-min pre-exposure } \\
+60 \text {-min swimming }\end{array}$ \\
\hline & Wil_\#3 & 21.3 & 122.1 & 31.3 & $\begin{array}{l}\text { Mean BW of } \\
4 \text { participants }\end{array}$ & $\begin{array}{l}\text { 5-min pre-exposure } \\
+30 \text {-min swimming } \\
+15 \text {-min intense swimming }\end{array}$ \\
\hline \multirow[t]{2}{*}{$\begin{array}{l}\text { Lindstrom } \\
\text { et al., } 1997\end{array}$} & Lin_\#1 & 70 & 145 & $2.5-4.5$ & Male BW & $\begin{array}{l}\text { 2h pre-exposure } \\
+2 \mathrm{~h} \text { intense swimming }(100 \mathrm{~W}) \\
+3 \mathrm{~h} \text { post-exposure }(50 \mathrm{~W})\end{array}$ \\
\hline & Lin_\#2 & 70 & 145 & $2.5-4.5$ & Female BW & $\begin{array}{l}2 \mathrm{~h} \text { pre-exposure } \\
+2 \mathrm{~h} \text { intense swimming }(100 \mathrm{~W}) \\
+3 \mathrm{~h} \text { post-exposure }(50 \mathrm{~W})\end{array}$ \\
\hline \multirow[t]{3}{*}{$\begin{array}{l}\text { Erdinger } \\
\text { et al., } 2004\end{array}$} & Erd_\#1 & 20.7 & 235 & 285 & BW by default & $\begin{array}{l}\text { 60-min swimming } \\
+10 \text {-min post-exposure in the pool } \\
\text { area }\end{array}$ \\
\hline & Erd_\#2 & 24.8 & 215 & 210 & BW by default & $\begin{array}{l}60 \text {-min swimming } \\
+10 \text {-min post-exposure in the pool } \\
\text { area }\end{array}$ \\
\hline & Erd_\#3 & 7.1 & 125 & 83 & BW by default & $\begin{array}{l}60 \text {-min swimming } \\
+10 \text {-min post-exposure in the pool } \\
\text { area }\end{array}$ \\
\hline \multirow{10}{*}{$\begin{array}{l}\text { Caro and } \\
\text { Gallego., } \\
2008\end{array}$} & Car_\#1 & 125 & 241 & 2.9 & BW by default & $\begin{array}{l}\text { 5-min pre-exposure } \\
+60 \text {-min swimming }\end{array}$ \\
\hline & Car_\#2 & 115 & 195 & 3.3 & BW by default & $\begin{array}{l}\text { 5-min pre-exposure } \\
+60 \text {-min swimming }\end{array}$ \\
\hline & Car_\#3 & 145 & 305 & 4.5 & BW by default & $\begin{array}{l}\text { 5-min pre-exposure } \\
+60 \text {-min swimming }\end{array}$ \\
\hline & Car_\#4 & 100 & 136 & 3.8 & BW by default & $\begin{array}{l}\text { 5-min pre-exposure } \\
+60 \text {-min swimming }\end{array}$ \\
\hline & Car_\#5 & 120 & 218 & 2.4 & BW by default & $\begin{array}{l}\text { 5-min pre-exposure } \\
+60 \text {-min swimming }\end{array}$ \\
\hline & Car_\#6 & 85 & 92 & 3.3 & BW by default & $\begin{array}{l}\text { 5-min pre-exposure } \\
+60 \text {-min swimming }\end{array}$ \\
\hline & Car_\#7 & 130 & 254 & 4.2 & BW by default & $\begin{array}{l}\text { 5-min pre-exposure } \\
+60 \text {-min swimming }\end{array}$ \\
\hline & Car_\#8 & 155 & 340 & 5 & BW by default & $\begin{array}{l}\text { 5-min pre-exposure } \\
+60 \text {-min swimming }\end{array}$ \\
\hline & Car_\#9 & 150 & 324 & 4.8 & BW by default & $\begin{array}{l}\text { 5-min pre-exposure } \\
+60 \text {-min swimming }\end{array}$ \\
\hline & Car_\#10 & 110 & 187 & 4.6 & BW by default & $\begin{array}{l}\text { 5-min pre-exposure } \\
+60 \text {-min swimming }\end{array}$ \\
\hline
\end{tabular}


Table 3. Maximal venous concentrations (Cv max), absorbed doses (AD), and pulmanory (INHAL) and dermal (DERM) relative contributions to total absorbed doses predicted for the various simulated exposure scenarios

\begin{tabular}{|c|c|c|c|c|c|}
\hline \multicolumn{2}{|l|}{ Simulation reference } & $\operatorname{Cvmax}(\mu \mathrm{g} / \mathrm{L})$ & $\mathrm{AD}(\mu \mathrm{g} / \mathrm{kg})$ & INHAL (\%) & DERMAL(\%) \\
\hline \multicolumn{6}{|c|}{ Swimming pool exposure $(1 \mathrm{~h}$ or $2 \mathrm{~h})$} \\
\hline \multirow[t]{5}{*}{ Lévesque et al., 1994} & Lev_\#1 & 5.15 & 16.39 & 65 & 35 \\
\hline & Lev_\#2 & 31.5 & 112.44 & 94 & 6 \\
\hline & Lev_\#3 & 10.9 & 34.5 & 68 & 32 \\
\hline & Lev_\#4 & 15.81 & 50.74 & 60 & 40 \\
\hline & Lev_\#5 & 16.81 & 53.43 & 63 & 37 \\
\hline \multirow[t]{3}{*}{ Wilson, 1995} & Wil_\#1 & 0.286 & 0.987 & 13 & 87 \\
\hline & Wil_\#2 & 0,239 & 0.875 & 15 & 85 \\
\hline & Wil_\#3 & 0.621 & 1.310 & 55 & 45 \\
\hline \multirow[t]{2}{*}{ Lindstrom et al., 1997} & Lin_\#1 & 1.70 & 12.65 & 55 & 45 \\
\hline & Lin_\#2 & 1.71 & 13.01 & 55 & 45 \\
\hline \multirow[t]{3}{*}{ Erdinger et al., 2004} & Erd_\#1 & 0.61 & 2.11 & 61 & 39 \\
\hline & Erd_\#2 & 0.58 & 2.13 & 54 & 46 \\
\hline & Erd_\#3 & 0.26 & 0.92 & 70 & 30 \\
\hline \multirow[t]{10}{*}{ Caro and Gallego., 2008} & Car_\#1 & 1.66 & 6.08 & 18 & 82 \\
\hline & Car_\#2 & 1.49 & 5.47 & 16 & 84 \\
\hline & Car_\#3 & 1.97 & 7.17 & 19 & 81 \\
\hline & Car_\#4 & 1.25 & 4.68 & 13 & 87 \\
\hline & Car_\#5 & 1.58 & 5.77 & 17 & 83 \\
\hline & Car_\#6 & 1.02 & 3.81 & 11 & 89 \\
\hline & Car_\#7 & 1.74 & 6.34 & 18 & 82 \\
\hline & Car_\#8 & 2.12 & 7.72 & 20 & 80 \\
\hline & Car_\#9 & 2.04 & 7.47 & 20 & 80 \\
\hline & Car_\#10 & 1.43 & 5.24 & 16 & 80 \\
\hline \multicolumn{6}{|l|}{ Household exposure (24h) } \\
\hline \multirow{2}{*}{\multicolumn{2}{|c|}{$\begin{array}{l}\text { Scenario from Haddad et al. (2006) } \\
\text { Scenario from Nuckols et al. (2005) }\end{array}$}} & 0.65 & 2.27 & 32 & 21 \\
\hline & & & & & \\
\hline \multicolumn{2}{|c|}{ low contamination $(30 \mu \mathrm{g} / \mathrm{L})$} & 0.20 & 0.91 & 30 & 30 \\
\hline \multicolumn{2}{|c|}{ high contamination $(100 \mu \mathrm{g} / \mathrm{L})$} & 0.88 & 3.43 & 39 & 24 \\
\hline
\end{tabular}

On the basis of their measurements of TCM in exhaled air, Wilson (1995), Lévesque et al. (1994) and Erdinger et al. (2004) concluded that inhalation was the major route of exposure to this compound. Lévesque (1994) and Erdinger (2004) estimated this contribution at approximately $24 \%$ and that one third of body burden resulted from dermal absorption. Our predictions are in good agreement with their estimates. Contrary to these authors, Lindstrom (1997) reported that the dermal route prevailed primarily over the respiratory route $(80 \%$ of the blood concentration in TCM). PBTK modeling did not predict that dermal absorption contributed so greatly to the total exposure in this case, but estimated a contribution of this pathway clearly higher than that established for the previously mentioned studies. In the simulations carried out with data from Lindstrom et al. (1997), biological air alveolar predictions misestimated actually measured levels. This may be attributable to an underestimation of skin absorption by the PBTK model in this particular study case where swimmers in training were subjected to very intense physiological efforts. However, interestingly enough, we confirmed that dermal absorption could be 
more important than other studies suggested. Likewise, for scenarios from Caro and Gallego (2008a) and Wilson (1995), with either high water contamination and comparatively low air pollution or both low water and air contamination compared to usually reported levels, respectively, we predicted skin absorption could contribute more than $80 \%$ of total TCM intake, as reported by Lindstrom et al. (1994). Interestingly, as shown in Figure 4, the relative contributions of each route to TCM exposure resulting from approximately one hour swimming were determined by the ratio of air contamination $\left(C_{\text {inhs }}\right.$ in $\left.\mu \mathrm{g} / \mathrm{m}^{3}\right)$ on water contamination $\left(\mathrm{C}_{\mathrm{wat}}\right.$ in $\mu \mathrm{g} / \mathrm{L}$ ) (data from Lindstrom corresponding to a longer exposure were excluded). It appears that when TCM air concentration (in $\mu \mathrm{g} / \mathrm{m}^{3}$ ) is more than approximately eight times the TCM concentration in water (in $\mu \mathrm{g} / \mathrm{L}$ ), inhalation is the major exposure pathway. Above this value, the dermal route would prevail.

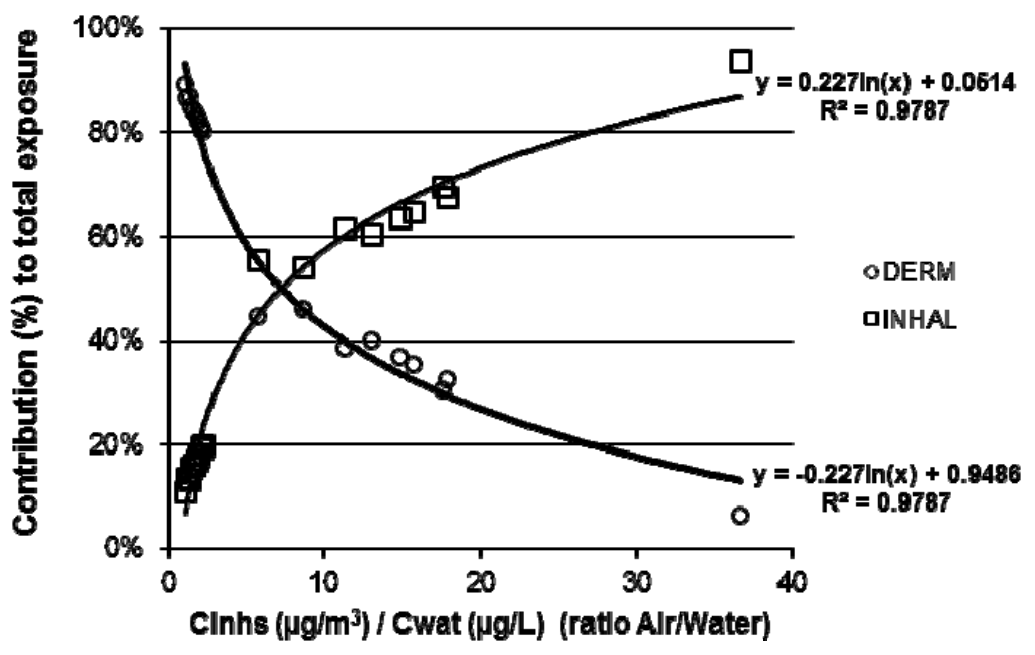

Figure 4. Relative contributions of dermal (DERM) and respiratory (INHAL) pathways according the ratio of environmental air (Cinhs) and water (Cwat) concentrations

Finally, we compared $\mathrm{Cv}$ max and $\mathrm{AD}$ resulting from short-time (1-2h) swimming pool exposures versus following long-time $(24 \mathrm{~h})$ household exposure. Interestingly, the predicted quantities of contaminant absorbed in a few minutes in a swimming pool are at least equivalent to those absorbed over 24-h at home ([0.875-112.44] vs. [0.91-3.43] $\mu \mathrm{g} / \mathrm{kg}$, respectively). The same conclusion, addressed for the first time, applies to the maximal venous concentration $([0.26-31.25]$ vs $[0.2-0.88] \mu \mathrm{g} / \mathrm{L})$. Apart from the cases when low environmental contamination of pool were reported (Wil_\#1, Wil_\#2, Wil_\#3 and Erd_\#3), Cv max and AD are always higher following swimming pool exposure versus typical household exposure if the physiological impacts of effort for improving our predictions are considered, as shown in Figure 3.

\section{Discussion and Conclusions}

\subsection{Advantages and Reliability of PBTK Modeling}

PBTK modeling is a powerful and practical tool that can facilitate the assessment of exposure in epidemiological investigations, especially when multi-route exposure is involved. It was used recently to estimate household exposure in a study on adverse reproductive outcomes and exposure to THMs (including TCM) (Levallois et al., 2012). The use of PBTK modeling to assess additional or separate exposure to TCM resulting from swimming pool attendance is worth further exploring. The approach was tested earlier regarding TCM exposure in competitive swimmers (Lévesque et al., 2000)

Our predictions using PBTK modeling appear to adequately simulate real swimming pool exposure scenarios and the relative biological measurements reported in the more detailed studies extracted from the literature. In all cases, the same tendencies and similar exposure profiles were found between modeled predictions and reported measurements, which tend to confirm the robustness of the PBTK model developed by Haddad et al. (2006) and its suitability to efficiently assess and easily predict multi-route exposures to TCM.

The PBTK modeling suggested that the relative proportions to TCM exposure attributable to dermal and pulmonary routes after one hour of swimming depend on environmental concentrations. Nevertheless, this result should be regarded with caution. As a matter of fact, Lévesque et al. (1994) reported strong correlations between TCM concentrations in water and alveolar air, which is not necessarily contradictory to a prevalent contribution 
of inhalation to exposure. Conversely, a recent study by Font-Ribeira et al. (2010) established a significant correlation between TCM levels in exhaled air with levels in ambient air, but not with levels in water. This suggests that exposure may be influenced primarily by respiratory absorption. However, the mean contamination levels reported $\left(16.1+/-3.4 \mu \mathrm{g} / \mathrm{L}\right.$ in water and $35.0+/-12.3 \mu \mathrm{g} / \mathrm{m}^{3}$ in the air) would indicate a higher contribution of dermal absorption, according to our statement. On the other hand, using a fugacity model, Dyck et al. (2011) previously demonstrated that the proportion of exposure attributable to dermal absorption can be just as important as inhalation for TCM, which is consistent with our results. These latter authors also established this proportion change according to the age of exposed individual and for other THMs.

\subsection{Comparison with Other Approaches}

Various approaches available to assess individual exposure to TCM in swimming pools include (i) the use of the SWIMODEL software (U.S.E.P.A., 2003), (ii) the use of uptake factors (UF) (Villanueva, Gagniere et al., 2007) or (iii) fugacity modeling (Dyck et al., 2011). However, PBTK modeling may offer an attractive balance between practicability, efficiency and reliability, although it is certainly the less easy-to-use approach and the most demanding for parameterization. However, it can serve to predict a greater number of different outputs (dose surrogates) than all other approaches. Additionally, PBTK modeling involves mechanisms that make it more plausible biologically and predictions more relevant. For instance, if we compare the predictions resulting from the UF approach with the same appropriate outputs from PBTK modeling for the 23 scenarios of swimming pool exposure previously examined, ratios between the estimates from each method vary between 0.17 and 3.25. Although interesting and very practical for epidemiological purposes, the UF approach does not suffice to distinguish the specific contributions of each absorption pathway in the total exposure quantification, nor does it consider the particular physiological characteristics of the exposed individuals while generalizing a particular case. The PBTK modeling approach, on the other hand, allows consideration of the characteristics of individuals and exposure conditions (for example, adaptation of pulmonary ventilation), appearing, therefore, to be more suitable for assessing "real" exposure.

\subsection{Limitations, Challenges and Perspectives}

A main limitation of this study concerns the fact that swimming is actually simulated as showering or bathing. To date, only the duration of the activity serves to distinguish these various exposure events for PBTK modeling. Future research should address this issue, perhaps by exploring distinct ways of modeling skin absorption. In the current state of knowledge, such assumptions are unavoidable.

The intensity of physical activity and its impact on a subject's physiological characteristics while swimming should be specified and accounted for to optimize the predictions of the internal concentrations. The feasibility and possibility of assessing the physical efforts of an individual during his/her swimming exercise in order to account for their potential impact on his/her physiology and improve prediction accuracy is particularly challenging from the perspective of standardizing the use of PBTK modeling for exposure assessment.

Precisely predicting the actual values of contaminant concentrations in water and air at the exact time of the exposure appears is another important issue, given that field measurements are often hard to obtain or not necessarily available. For the present investigation, we selected only studies documenting actual environmental levels for both water and air in order to mitigate any additional uncertainties. Other investigations should address the predictive modeling of these environmental levels.

Likewise, simulations for this preliminary exploration of PBTK modeling as a tool for swimming pool exposure assessment were performed for typical adult swimmers or competitors. Swimming pool exposure of other potentially sensitive populations (e.g., children, workers and pregnant women) should also be addressed. As mentioned earlier, the work of Dyck et al. (2011) in particular underlined the change in TCM exposure depending on the age of the exposed individual.

Obviously, similar studies should be reproduced for other THMs (whose specific chemical properties can modify the contaminant fate in the organism), but very few data are available in the literature which could serve to validate the models for other THMs.

Moreover, our study focused on alveolar air and blood as biomarkers. Further investigation could evaluate the predictions of TCM levels in urine using an upgraded PBTK model for comparison with the few data reported in the literature (Cammann \& Hubner, 1995; Caro \& Gallego, 2007, 2008a; Caro et al., 2007).

Finally, the results of this study corroborate other investigations that point out the importance of swimming pool exposure compared to typical household exposure (Font-Ribera, Kogevinas, Nieuwenhuijsen et al., 2010; Villanueva et al., 2006; Villanueva, Gagniere et al., 2007). Such results should lead to further investigation on 
exposure to TCM (and DBPs) in other places such as hot tubs.

\section{Acknowledgments}

The authors acknowledge the Réseau de recherche en santé environnementale (Québec) and the Agence française de sécurité sanitaire de l'environnement et au travail (AFSSET) for funding. They also thank Ms. Janet Brownlee for idiomatic corrections.

\section{References}

AFSSET. (2010). Risques sanitaires liés aux piscines - Évaluation des risques sanitaires liés aux piscines. Partie 1: piscines réglementées. Avis de l'Afsset. Rapport d'expertise collective.

Aggazzotti, G., Fantuzzi, G., Righi, E., \& Predieri, G. (1995). Environmental and biological monitoring of chloroform in indoor swimming pools. J. Chromatogr. A, 710(1), 181-190. http://dx.doi.org/10.1016/0021-9673(95)00432-M

Aggazzotti, G., Fantuzzi, G., Righi, E., \& Predieri, G. (1998). Blood and breath analyses as biological indicators of exposure to trihalomethanes in indoor swimming pools. Sci. Total Environ., 217(1-2), 155-163. http://dx.doi.org/10.1016/S0048-9697(98)00174-0

Aggazzotti, G., Fantuzzi, G., Righi, E., Tartoni, P., Cassinadri, T., \& Predieri, G. (1993). Chloroform in alveolar air of individuals attending indoor swimming pools. Arch. Environ. Health, 48(4), 250-254. http://dx.doi.org/10.1080/00039896.1993.9940368

Aggazzotti, G., Fantuzzi, G., Tartoni, P. L., \& Predieri, G. (1990). Plasma chloroform concentrations in swimmers using indoor swimming pools. Arch. Environ. Health, 45(3), 175-179. http://dx.doi.org/10.1080/00039896.1990.9936712

Aiking, H., van Acker, M. B., Scholten, R. J., Feenstra, J. F., \& Valkenburg, H. A. (1994). Swimming pool chlorination: a health hazard? Toxicol. Lett., $72(1-3), \quad 375-380$. http://dx.doi.org/10.1016/0378-4274(94)90051-5

Beech, A. J. (1980). Estimated worst case trihalomethane body burden of a child using a swimming pool. Medical hypotheses, 6, 303-307. http://dx.doi.org/10.1016/0306-9877(80)90127-9

Bessonneau, V., Derbez, M., Clement, M., \& Thomas, O. (2011). Determinants of chlorination by-products in indoor swimming pools. Int. J. Hyg. Environ. Health, 215(1), 76-85. http://dx.doi.org/10.1016/j.ijheh.2011.07.009

Cammann, K., \& Hubner, K. (1995). Trihalomethane concentrations in swimmers' and bath attendants' blood and urine after swimming or working in indoor swimming pools. Arch. Environ. Health, 50(1), 61-65. http://dx.doi.org/10.1080/00039896.1995.9955013

Caro, J., \& Gallego, M. (2007). Assessment of exposure of workers and swimmers to trihalomethanes in an indoor swimming pool. Environ. Sci. Technol., 4l(13), 4793-4798. http://dx.doi.org/10.1021/es070084c

Caro, J., \& Gallego, M. (2008a). Alveolar air and urine analyses as biomarkers of exposure to trihalomethanes in an indoor swimming pool. Environ. Sci. Technol., 42(13), 5002-5007. http://dx.doi.org/10.1021/es800415p

Caro, J., \& Gallego, M. (2008b). Development of a sensitive thermal desorption method for the determination of trihalomethanes in humid ambient and alveolar air. Talanta, 76(4), 847-853. http://dx.doi.org/10.1016/j.talanta.2008.04.044

Caro, J., Serrano, A., \& Gallego, M. (2006). Sensitive headspace gas chromatography-mass spectrometry determination of trihalomethanes in urine. J. Chromatogr. B Analyt. Technol Biomed. Life Sci., 848(2), 277-282. http://dx.doi.org/10.1016/j.jchromb.2006.10.034

Caro, J., Serrano, A., \& Gallego, M. (2007). Sensitive headspace gas chromatography-mass spectrometry determination of trihalomethanes in urine. J. Chromatogr. B Analyt. Technol. Biomed. Life Sci., 848(2), 277-282. http://dx.doi.org/10.1016/j.jchromb.2006.10.034

Chu, H., \& Nieuwenhuijsen, M. J. (2002). Distribution and determinants of trihalomethane concentrations in indoor swimming pools. Occup. Environ. Med., 59(4), 243-247. http://dx.doi.org/10.1136/oem.59.4.243

Costeff, H. (1966). A simple empirical formula for calculating approximate surface area in children. Arch. Dis. Child, 41(220), 681-683. http://dx.doi.org/10.1136/adc.41.220.681

Dodds, L., King, W., Allen, A. C., Armson, B. A., Fell, D. B., \& Nimrod, C. (2004). Trihalomethanes in public water supplies and risk of stillbirth. Epidemiology, 15(2), 179-186. 
http://dx.doi.org/10.1097/01.ede.0000112209.47765.d9

Dufour, A. P., Evans, O., Behymer, T. D., \& Cantu, R. (2006). Water ingestion during swimming activities in a pool: a pilot study. $J$ Water Health, 4(4), 425-430.

Dyck, R., Sadiq, R., Rodriguez, M. J., Simard, S., \& Tardif, R. (2011). Trihalomethane exposures in indoor swimming pools: A level III fugacity model. Water Res. 45(16), 5084-98 http://dx.doi.org/10.1016/j.watres.2011.07.005

Erdinger, L., Kuhn, K. P., Kirsch, F., Feldhues, R., Frobel, T., Nohynek, B. et al. (2004). Pathways of trihalomethane uptake in swimming pools. Int. J. Hyg. Environ Health, 207(6), 571-575. http://dx.doi.org/10.1078/1438-4639-00329

Fantuzzi, G., Righi, E., Predieri, G., Ceppelli, G., Gobba, F., \& Aggazzotti, G. (2001). Occupational exposure to trihalomethanes in indoor swimming pools. Sci Total Environ, 264(3), 257-265. http://dx.doi.org/10.1016/S0048-9697(00)00722-1

Fantuzzi, G., Righi, E., Predieri, G., Giacobazzi, P., Mastroianni, K., \& Aggazzotti, G. (2010). Prevalence of ocular, respiratory and cutaneous symptoms in indoor swimming pool workers and exposure to disinfection by-products (DBPs). Int. J. Environ. Res. Public Health, 7(4), 1379-1391. http://dx.doi.org/10.3390/ijerph7041379

Faust, B., Faust, M., \& Cammann, K. (1993). Determination of volatile halogenated hydrocarbons in swimmers'exhalations influenced by indoor swimming pool air. Proceedings of Indoor Air'93, 3, 379-381.

Font-Ribera, L., Kogevinas, M., Nieuwenhuijsen, M. J., Grimalt, J. O., \& Villanueva, C. M. (2010). Patterns of water use and exposure to trihalomethanes among children in Spain. Environ. Res., 110(6), 571-579. http://dx.doi.org/10.1016/j.envres.2010.05.008

Font-Ribera, L., Kogevinas, M., Zock, J. P., Gomez, F. P., Barreiro, E., Nieuwenhuijsen, M. J. et al. (2010). Short-Term Changes in Respiratory Biomarkers after Swimming in a Chlorinated Pool. Environ. Health Perspect, 118(11), 1538-44. http://dx.doi.org/10.1289/ehp.1001961

Gallagher, M. D., Nuckols, J. R., Stallones, L., \& Savitz, D. A. (1998). Exposure to trihalomethanes and adverse pregnancy outcomes. Epidemiology, 9(5), 484-489. http://dx.doi.org/10.1097/00001648-199809000-00003

Grazuleviciene, R., Nieuwenhuijsen, M. J., Vencloviene, J., Kostopoulou-Karadanelli, M., Krasner, S. W., Danileviciute, A. et al. (2011). Individual exposures to drinking water trihalomethanes, low birth weight and small for gestational age risk: a prospective Kaunas cohort study. Environ. Health, 10, 32. http://dx.doi.org/10.1186/1476-069X-10-32

Grellier, J., Bennett, J., Patelarou, E., Smith, R. B., Toledano, M. B., Rushton, L. et al. (2010). Exposure to disinfection by-products, fetal growth, and prematurity: a systematic review and meta-analysis. Epidemiology, 21(3), 300-313. http://dx.doi.org/10.1097/EDE.0b013e3181d61ffd

Haddad, S., Charest-Tardif, G. C., \& Tardif, R. (2006). Development of physiologically based toxicokinetic models for improving the human indoor exposure assessment to water contaminants: trichloroethylene and

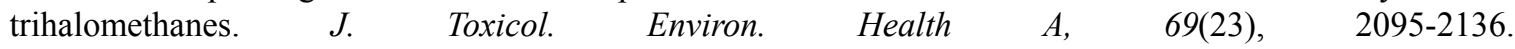
http://dx.doi.org/10.1080/15287390600631789

Hinckley, A. F., Bachand, A. M., \& Reif, J. S. (2005). Late pregnancy exposures to disinfection by-products and growth-related birth outcomes. Environ Health Perspect., 113(12), 1808-1813. http://dx.doi.org/10.1289/ehp.8282

Hoffman, C. S., Mendola, P., Savitz, D. A., Herring, A. H., Loomis, D., Hartmann, K. E. et al. (2008a). Drinking water disinfection by-product exposure and duration of gestation. Epidemiology, 19(5), 738-746.

Hoffman, C. S., Mendola, P., Savitz, D. A., Herring, A. H., Loomis, D., Hartmann, K. E. et al. (2008b). Drinking water disinfection by-product exposure and fetal growth. Epidemiology, 19(5), 729-737. http://dx.doi.org/10.1097/EDE.0b013e3181812beb

Kogevinas, M., Villanueva, C. M., Font-Ribera, L., Liviac, D., Bustamante, M., Espinoza, F. et al. (2010). Genotoxic Effects in Swimmers Exposed to Disinfection By-products in Indoor Swimming Pools. Environ. Health Perspect., 118(11),1538-44. http://dx.doi.org/10.1289/ehp.1001959

Krishnan, K., Haddad, S., Beliveau, M., \& Tardif, R. (2002). Physiological modeling and extrapolation of pharmacokinetic interactions from binary to more complex chemical mixtures. Environ Health Perspect, 110 Suppl 6, 989-994. http://dx.doi.org/10.1289/ehp.02110s6989 
Lee, J., Ha, K. T., \& Zoh, K. D. (2009). Characteristics of trihalomethane (THM) production and associated health risk assessment in swimming pool waters treated with different disinfection methods. Sci. Total Environ., 407(6), 1990-1997. http://dx.doi.org/10.1016/j.scitotenv.2008.11.021

Lee, J., Jun, M. J., Lee, M. H., Eom, S. W., \& Zoh, K. D. (2010). Production of various disinfection byproducts in indoor swimming pool waters treated with different disinfection methods. Int. J. Hyg. Environ. Health, 213(6), 465-474. http://dx.doi.org/10.1016/j.ijheh.2010.09.005

Levallois, P., Gingras, S., Marcoux, S., Legay, C., Catto, C., Rodriguez, M. et al. (2012). Small-for-gestational-age neonates and maternal exposure to chlorination by-products. Epidemiology, (in press).

Lévesque, B., Ayotte, P., LeBlanc, A., Dewailly, E., Prud'Homme, D., Lavoie, R. et al. (1994). Evaluation of dermal and respiratory chloroform exposure in humans. Environ Health Perspect., 102(12), 1082-1087. http://dx.doi.org/10.1289/ehp.941021082

Lévesque, B., Ayotte, P., Tardif, R., Charest-Tardif, G., Dewailly, E., Prud'Homme, D. et al. (2000). Evaluation of the health risk associated with exposure to chloroform in indoor swimming pools. J. Toxicol. Environ Health A, 61(4), 225-243. http://dx.doi.org/10.1080/00984100050136553

Lindstrom, A. B., Pleil, J. D., \& Berkoff, D. C. (1997). Alveolar breath sampling and analysis to assess trihalomethane exposures during competitive swimming training. Environ. Health Perspect., 105(6), 636-642. http://dx.doi.org/10.1289/ehp.97105636

Lourencetti, C., Ballester, C., Fernandez, P., Marco, E., Prado, C., Periago, J. F. et al. (2010). New method for determination of trihalomethanes in exhaled breath: applications to swimming pool and bath environments. Anal. Chim. Acta, 662(1), 23-30. http://dx.doi.org/10.1016/j.aca.2009.12.040

MacLehose, R. F., Savitz, D. A., Herring, A. H., Hartmann, K. E., Singer, P. C., \& Weinberg, H. S. (2008). Drinking water disinfection by-products and time to pregnancy. Epidemiology, 19(3), 451-458. http://dx.doi.org/10.1097/EDE.0b013e31816a23eb

Nieuwenhuijsen, M. J., Grellier, J., Smith, R., Iszatt, N., Bennett, J., Best, N. et al. (2009). The epidemiology and possible mechanisms of disinfection by-products in drinking water. Philos Transact A Math. Phys. Eng. Sci., 367(1904), 4043-4076. http://dx.doi.org/10.1098/rsta.2009.0116

Nuckols, J. R., Ashley, D. L., Lyu, C., Gordon, S. M., Hinckley, A. F., \& Singer, P. (2005). Influence of tap water quality and household water use activities on indoor air and internal dose levels of trihalomethanes. Environ Health Perspect., 113(7), 863-870. http://dx.doi.org/10.1289/ehp.7141

Panyakapo, M., Soontornchai, S., \& Paopuree, P. (2008). Cancer risk assessment from exposure to trihalomethanes in tap water and swimming pool water. J. Environ. Sci. (China), 20(3), 372-378. http://dx.doi.org/10.1016/S1001-0742(08)60058-3

Patelarou, E., Kargaki, S., Stephanou, E. G., Nieuwenhuijsen, M., Sourtzi, P., Gracia, E. et al. (2011). Exposure to brominated trihalomethanes in drinking water and reproductive outcomes. Occup. Environ. Med., 68(6), 438-445. http://dx.doi.org/10.1136/oem.2010.056150

Porter, C. K., Putnam, S. D., Hunting, K. L., \& Riddle, M. R. (2005). The effect of trihalomethane and haloacetic acid exposure on fetal growth in a Maryland county. Am. J. Epidemiol., 162(4), 334-344. http://dx.doi.org/10.1093/aje/kwi211

Sa, C. S., Boaventura, R. A., \& Pereira, I. B. (2011). Analysis of trihalomethanes in water and air from indoor swimming pools using HS-SPME/GC/ECD. J. Environ. Sci. Health A Tox. Hazard. Subst. Environ. Eng., 46(4), 355-363. http://dx.doi.org/10.1080/10934529.2011.542385

Sacré, C., Schwenk, M., Jovanovic, S., Wallner, T., \& Gabrio, T. (1996). Presence of haloforms in pool water, ambient air and in swimmers and lifeguards in outdoor and indoor pools. A. B. Archiv des Badewesens, 49, 105-109.

Savitz, D. A., Singer, P. C., Herring, A. H., Hartmann, K. E., Weinberg, H. S., \& Makarushka, C. (2006). Exposure to drinking water disinfection by-products and pregnancy loss. Am. J. Epidemiol, 164(11), 1043-1051. http://dx.doi.org/10.1093/aje/kwj300

Simard, S. (2009). Occurrence des sous-produits de la désinfection dans l'eau des piscines publiques de la ville de Québec., Université Laval.

Tardif, R., Droz, P. O., Charest-Tardif, G., Pierrehumbert, G., \& Truchon, G. (2002). Impact of human variability 
on the biological monitoring of exposure to toluene: I. Physiologically based toxicokinetic modelling. Toxicol. Lett., 134(1-3), 155-163. http://dx.doi.org/10.1016/S0378-4274(02)00185-6

Tardiff, R. G., Carson, M. L., \& Ginevan, M. E. (2006). Updated weight of evidence for an association between adverse reproductive and developmental effects and exposure to disinfection by-products. Regul.Toxicol.Pharmacol., 45(2), 185-205. http://dx.doi.org/10.1016/j.yrtph.2006.03.001

U.S.E.P.A. (2003). User's manual Swimmer Exposure Assessment Model (SWIMODEL) Version 3.0.

Villanueva, C. M., Cantor, K. P., Grimalt, J. O., Castano-Vinyals, G., Malats, N., Silverman, D. et al. (2006). Assessment of lifetime exposure to trihalomethanes through different routes. Occup. Environ Med., 63(4), 273-277. http://dx.doi.org/10.1136/oem.2005.023069

Villanueva, C. M., Cantor, K. P., Grimalt, J. O., Malats, N., Silverman, D., Tardon, A. et al. (2007). Bladder cancer and exposure to water disinfection by-products through ingestion, bathing, showering, and swimming in pools. Am. J. Epidemiol., 165(2), 148-156. http://dx.doi.org/10.1093/aje/kwj364

Villanueva, C. M., Gagniere, B., Monfort, C., Nieuwenhuijsen, M. J., \& Cordier, S. (2007). Sources of variability in levels and exposure to trihalomethanes. Environ. Res., 103(2), 211-220. http://dx.doi.org/10.1016/j.envres.2006.11.001

Villanueva, C. M., Gracia-Lavedan, E., Ibarluzea, J., Santa, M. L., Ballester, F., Llop, S. et al. (2011). Exposure to Trihalomethanes through Different Water Uses and Birth Weight, Small for Gestational Age and Preterm Delivery in Spain. Environ. Health Perspect, 119(12):1824-30. http://dx.doi.org/10.1289/ehp.1002425

Weaver, W. A., Li, J., Wen, Y., Johnston, J., Blatchley, M. R., \& Blatchley, E. R., III. (2009). Volatile disinfection by-product analysis from chlorinated indoor swimming pools. Water Res., 43(13), 3308-3318. http://dx.doi.org/10.1016/j.watres.2009.04.035

Weisel, C. P., \& Jo, W. K. (1996). Ingestion, inhalation, and dermal exposures to chloroform and trichloroethene from tap water. Environ. Health Perspect., 104(1), 48-51. http://dx.doi.org/10.1289/ehp.9610448

Whitaker, H. J., Nieuwenhuijsen, M. J., \& Best, N. G. (2003). The relationship between water concentrations and individual uptake of chloroform: a simulation study. Environ. Health Perspect., 111(5), 688-694. http://dx.doi.org/10.1289/ehp.5963

Wilson, L. R. (1995). An assessment of dermal absorption and inhalation of chloroform by swimmers for the purposes of estimating dose. School of Public Health, State University of New York at Albany, Albany, NY.

Zwiener, C., Richardson, S. D., De Marini, D. M., Grummt, T., Glauner, T., \& Frimmel, F. H. (2007). Drowning in disinfection byproducts? Assessing swimming pool water. Environ. Sci. Technol, 41(2), 363-372. http://dx.doi.org/10.1021/es062367v 